\title{
The Influence of HR Competence and Intellectual Capital on the Performance of MSMEs in Sasirangan Craftsmen
}

\author{
Sampurnawati $^{\mathrm{a}} \&$ Titien Agustina ${ }^{\mathrm{b}, *}$ \\ ${ }^{a}$ Universitas Merdeka Malang, Indonesia \\ ${ }^{b}$ Sekolah Tinggi Ilmu Manajemen Indonesia (STIMI) Banjarmasin, Indonesia
}

\begin{abstract}
This study aims to (1) describe the competence of Human Resources (HR), intellectual capital and the performance of Micro, Small and Medium Enterprises (MSMEs) engaged in the production of Sasirangan, a typical cloth of South Kalimantan (2) Analyze the influence of the level of competence of Human Resources ( HR) and intellectual capital on the performance of Sasirangan MSMEs. (3) Analyzing the competence of Human Resources (HR) and intellectual capital have a dominant effect on the performance of Sasirangan SMEs. Associative research method on 40 respondents taken by total sampling method. The data analysis technique used multiple linear regression. The results showed that the competence of Human Resources (HR) and intellectual capital had a positive and significant effect on the performance of MSMEs. Between these two variables, intellectual capital has a more dominant influence on Sasirangan MSMEs.
\end{abstract}

Keywords: Human resources competency; intellectual capital; Performance of MSMEs.

\section{Introduction}

The low performance of MSMEs in achieving the success of a business, one of which is determined by the quality of Human Resources (HR) and the capital owned by MSME actors, including intellectual capital (Ardiana \& Brahmayanti, 2010); (Mufidah, Eva, \& Fibriyani, 2017); (Sulistiyani, 2017); (Hidayat \& Agustina, 2020). The synergy between the quality of human resources and proven intellectual capital makes MSMEs run optimally and are able to compete in the market. The problems that affect the performance of MSMEs can be reduced to several variables, namely HR competence and intellectual capital.

The problem of low performance of MSMEs caused by limited human resource competence and intellectual capital is also experienced by some Sasirangan craftsmen (a type of batik cloth typical of South Kalimantan) in Sasirangan Village, Banjar Regency, South Kalimantan Province. Although the growth of Sasirangan MSMEs in Banjar Regency, South Kalimantan is quite developed and has good prospects in the future, many still experience limitations in terms of human resource competence and intellectual capital. This was lifted from the results of surveys and interviews with several Sasirangan craftsmen that the obstacles faced by Sasirangan MSMEs in Banjar Regency were the weak competencies possessed by HR. Almost all Sasirangan craftsmen run a business with the same rules/regulations and habits from time to time in terms of production, marketing, and business management, even though these rules or habits are no longer in accordance with current market conditions. As a result, the products produced are still standing with the same materials, designs, and models, so that it seems monotonous and there are no other options. Lack of ideas, creativity, and the ability to innovate to create sasirangan products with different styles, images, and designs, which should differentiate them from competitors.

\footnotetext{
* Corresponding author.

E-mail address: titienagustina9@gmail.com (Titien Agustina)
} 
Sasirangan business actors in Sasirangan Village in Banjar Regency should be able to innovate products, namely by creating products in accordance with market needs and desires that continue to change from time to time, so that they remain in the midst of increasingly fierce business competition. Apart from that, the mindset aspect of the mindset of most of the Sasirangan MSME actors tends to still survive in the safe zone, where most of the MSME players only produce when there is an order. On the other hand, the ability of MSMEs to access capital from financial institutions or banks is also very limited because they cannot meet the requirements proposed by banks such as collateral guarantees, business licenses, etc., thus becoming another obstacle in efforts to develop and enlarge businesses.

Related to the guidance carried out by related parties, especially in providing training and counseling in order to increase the capacity of MSME actors from the government, in this case, the Office of Cooperatives and Small and Medium Enterprises (UKM), as well as the Office of Trade and Industry have been provided, but still have not touched a solution specifics with regard to the development of HR competencies and intellectual capital. For example, related to the lack of counseling about the importance of intellectual capital to make MSMEs more empowered and to advance in grade. In fact, the SMEs, especially the Sasirangan craftsmen, still have not fully utilized the existing potentials to improve business performance.

Based on the limited competency of human resources and intellectual capital related to the performance of MSMEs in Indonesia in general and in Banjar Regency, South Kalimantan in particular, especially the Sasirangan UMKM, the authors formulated the title of this study "The Effect of HR Competence and Intellectual Capital on the Performance of Sasirangan MSMEs in the Regency. Banjar. " The research objective was to analyze the influence of human resource competence and intellectual capital on the performance of Sasirangan MSMEs in Banjar Regency.

\section{Methods}

\subsection{Research design}

The type of research used is associative research (Sugiyono, 2011); (Sanusi, 2014), which is a method to find a correlation or causal relationship (a causal relationship). This research was conducted to prove the effectiveness of human resource competence and intellectual capital as independent variables on business performance as the dependent variable.

\subsection{Population and Sample}

The population who became the resource persons in this study were the Sasirangan craftsmen who were actively producing, located in Sasirangan Village, Kertak Hanyar District, Banjar Regency, as many as 40 people. In this case, the authors take samples based on field observations of micro, small, and medium enterprises (MSMEs) who are active in the production and are considered good at running their business. Sampling from this study was using total sampling, namely, all population sampled 40 respondents of Sasirangan MSMEs entrepreneurs in Banjar Regency.

\subsection{Data Analysis Technique}

\subsubsection{Multiple Linear Regression}

Researchers used Multiple Linear Regression Analysis in analyzing the data. Multiple regression is an analysis used to determine the relationship between one dependent variable and two or more independent variables.

Multiple linear regression test is used to test the truth of the hypothesis proposed in this study, the model is as follows:

$$
\mathrm{Y}=\alpha+\mathrm{b}_{1} \mathrm{X}_{1}+\mathrm{b}_{2} \mathrm{X}_{2}+\mathrm{e}
$$

with:

$\mathrm{Y}=$ MSME performance

$\mathrm{a}=$ Constanta

$\mathrm{b}_{1}=$ Regression coefficient for X1 
$\mathrm{b}_{2} \quad=$ Regression coefficient for X2

$\mathrm{X}_{1}=$ HR competencies

$\mathrm{X}_{2}=$ Intellectual capital

\subsection{Classic Assumption Test}

The classical assumption test is used to provide certainty that the regression equation obtained has accuracy in estimation, is unbiased and consistent. This test is used to see whether there are deviations from the assumptions of the classical model, namely by testing for normality, multicollinearity, heteroscedasticity, as follows:

\subsubsection{Normality Test}

The normality test aims to test whether the confounding or residual variables in the regression model have a normal distribution. To see the normality of the residuals is to look at the normal probability plot that compares the cumulative distribution of the normal distribution, by looking at the distribution of data (points) on the diagonal axis and graphs. The basis for the decision is that if the data spread around the diagonal line and follows the direction of the diagonal line, the regression model fulfills the assumption of normality.

\subsubsection{Multicollinearity Test}

The multicollinearity test aims to determine whether or not one or more independent variables have a relationship with other independent variables. In addition, this form is also to avoid habits in the decision-making process regarding the effect of the partial test of each independent variable on the dependent variable. If the value of the Variance Inflating Factor (VIF) $<10$ and the tolerance value $>0.1$ or $10 \%$, it can be concluded that the regression model does not occur multicollinearity.

\subsubsection{Heteroscedasticity Test}

How to test for heteroscedasticity with the Glejser method by compiling a regression between the absolute value of the residual and the free variable. If each independent variable does not have a significant effect on the absolute residual $(=0.05)$, then the regression model does not have heteroscedasticity symptoms.

\subsubsection{Hypothesis Testing}

\section{1) The t-test}

The t-test is a test of the individual partial regression coefficient which is used to determine whether the independent variable $(\mathrm{X})$ individually affects the dependent variable $(\mathrm{Y})$.

Based on hypothesis testing with the t-test, it can be explained as follows:

- If $\mathrm{t}$ count $>\mathrm{t}$ table, then $\mathrm{H} 0$ is rejected. Ha is accepted, so the independent variable partially has a significant effect on the dependent variable.

- If $\mathrm{t}$ count $<\mathrm{t}$ table then $\mathrm{HO}$ is accepted $\mathrm{Ha}$ is rejected, so the independent variable partially has no real influence on the dependent variable.

2) The F test

The $\mathrm{F}$ test is a test of the significance of the equation used to determine how much influence the independent variables collectively on the dependent variable. The criteria are as follows:

- If $\mathrm{F}$ count $>\mathrm{F}$ table (n-k-1), then $\mathrm{Ha}$ is accepted. This means that statistically existing data can prove that all independent variables (X1 and X2) have an effect on the dependent variable (Y).

- If $\mathrm{F}$ count $<\mathrm{F}$ table (n-k-1) then $\mathrm{Ha}$ is rejected. This means that statistically available data can prove that all independent variables (X1 and $\mathrm{X} 2$ ) have no effect on the dependent variable (Y). 


\subsubsection{Coefficient of Determination}

The coefficient of determination (R2) is a measure that shows the amount of variation in the dependent variable which can be explained by the independent variable. In other words, the coefficient of determination (R2) is used to measure how far the independent variables explain the dependent variable. As for this study using SPSS statistics.

\section{Result and Discussions}

Ciência \& Tecnologia dos Materiais accepts 1) Original Research Papers (Regular Papers); 2) Review Articles; and 3) Technical Notes.

\subsection{Data Analysis Result}

\subsubsection{Classic Assumption Test}

\section{1) Normality}

The results of the normality test can be performed using the P-P Plot of Residuals which is standardized from a regression analysis. Normal data if the dots are near or follow a straight line. The results of the regression analysis show that the points follow a straight line on the P-P plot as follows in fig. 1.

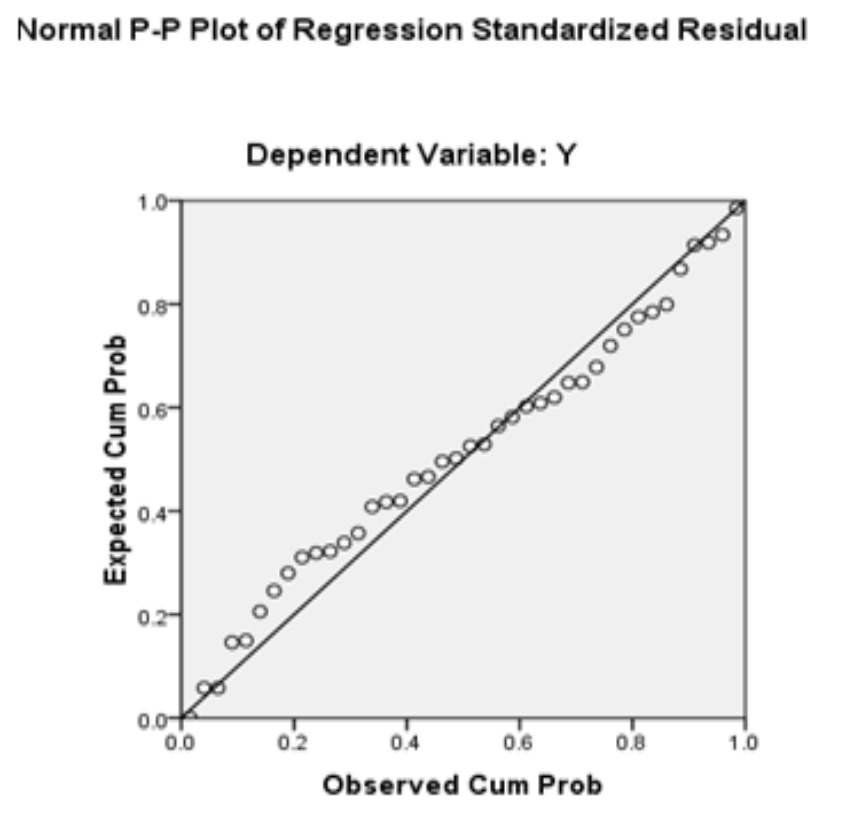

Fig. 1. P-P Plot

2) Liniearity

Table 1. Linearity Test Results

\begin{tabular}{llllll}
\hline No & Varibel & Linierity & $\begin{array}{l}\text { Deviation } \\
\text { Linearity }\end{array}$ & from & Criteria \\
\hline 1 & HR Competencies & 0.000 & 0.856 & $\begin{array}{l}\text { Linierity }<0,05 \text { dan Deviation } \\
\text { from Linearity }>0,05 \text { then the } \\
\text { data is linear }\end{array}$ \\
\hline 2 & Intellectual Capital & 0.000 & 0.696 & \\
\hline
\end{tabular}


The table 1 shows the values of linearity and deviation from linearity which can be used as benchmarks for determining data linearity. If linearity $<0.05$ and Deviation from Linearity $>0.05$, the data is linear. The linearity value for HR competence is 0.00 and intellectual capital also has a linearity of 0.00 . The value of deviation from linearity for HR competencies reaches 0.856 and intellectual capital has a deviation from linearity at 0.696 . So the HR competency linearity $<0.05$ with deviation from linearity $>0.05$. Intellectual capital linearity $<0.05$ with deviation from linearity $>0.05$. Thus the HR competency data and intellectual capital meet the linearity test.

3) Multicollinearity

Table 2. Multicollinearity Test Result

\begin{tabular}{llll}
\hline No. & Tolerance & VIF & Criteria \\
\hline 1. & 0.305 & 3.284 & $\begin{array}{l}\text { Tolerance }>0.05 \text { dan VIF }<10, \text { then the data does not } \\
\text { experience multicollinearity }\end{array}$ \\
\hline 2. & 0.305 & 3.284 & \\
\hline
\end{tabular}

The table 2 is used to explain the multicollinearity test results. The criteria used are if tolerance $>0.05$ and VIF $<10$, then the data does not experience multicollinearity. Tolerance for HR competencies $>0.1$ and tolerance for intellectual capital $>0.1$. The VIF value of HR competence was $3.284<10$ and the VIF value of intellectual capital was <10. So the two questionnaires for HR competence and intellectual capital did not experience multicollinearity.

\subsubsection{Regression Analysis Results}

1) $U j i R^{2}$

Table 3. Determinant Coefficient $\left(\mathrm{R}^{2}\right)$

\begin{tabular}{cccc}
\hline Model & $\mathrm{R}$ & R Square & Adjusted R Square \\
\hline 1 & $0.869^{\mathrm{a}}$ & 0.755 & 0.742 \\
\hline
\end{tabular}

The table 3 explains the percentage effect of HR competencies and intellectual capital on performance. The coefficient of determination (R2) of 0.755 is the result of the square of 0.869 . The determinant coefficient of $0.755 \mathrm{X}$ $100 \%=75.5 \%$ is the percentage of the influence of HR competence and intellectual capital on the performance of MSMEs. The rest, the performance of MSMEs is influenced by other variables besides HR competence and intellectual capital by $24.5 \%$.

2) The t-test

Table 4. Regression Coefficient

\begin{tabular}{llcccc}
\hline \multirow{2}{*}{ Model } & \multicolumn{2}{c}{ Unstandardized Coefficients } & \multirow{2}{*}{$\mathrm{t}$} & Sig. \\
\cline { 2 - 4 } & $\mathrm{B}$ & Std. Error & & \\
\hline \multirow{2}{*}{1} & (Constant) & 5.966 & 3.957 & 1.508 & 0.140 \\
\cline { 2 - 5 } $\mathrm{X} 1$ & 0.208 & 0.093 & 2.241 & 0.031 \\
\cline { 2 - 4 } $\mathrm{X} 2$ & 0.461 & 0.118 & 3.900 & 0.000 \\
\hline
\end{tabular}

The table 4 shows the regression coefficient used to explain the partial effect of HR competence and intellectual capital on the performance of MSMEs. The criterion used to test the effect was significance $<0.05$. If the significance 
$<0.05$, there is a significant effect of the independent variables on the dependent variable. The significance value of the influence of HR competencies on the performance of MSMEs is 0.0311. The significance value of the influence of intellectual capital on the performance of MSMEs is 0,000 . So the competence of human resources and intellectual capital partially affects the performance of MSMEs.

The independent variable which has a dominant effect on the dependent variable is done by comparing the $t$ value. If the $t$ value of the independent variable's influence on the dependent variable is greater than the others, the variable has a dominant effect. The $t$ value of the influence of HR competence on the performance of MSMEs is 2.241 and the $t$ value of the influence of intellectual capital on the performance of MSMEs is 3.900. With the t value of intellectual capital > the t value of HR competence, it can be concluded that intellectual capital has a dominant influence on the performance of MSMEs.

3) The F-Test

Table 5. The F Test Results

\begin{tabular}{llll}
\hline df & F tabel & F & Sig. \\
\hline $\begin{array}{l}2 \\
37\end{array}$ & 3,32 & 57.153 & 0.000 \\
\hline 39 & & \\
\hline
\end{tabular}

The table 5 is used to test this research model which shows the simultaneous influence of HR competencies and intellectual capital on the performance of MSMEs simultaneously. The criteria used are the comparison of the F value and significance. If the value of $\mathrm{F}$ count $>\mathrm{F}$ table and significant $<0.05$, this research model is appropriate and the independent variables of HR competence and intellectual capital have a simultaneous effect on the performance of MSMEs.

\subsubsection{Hypothesis Test}

The criteria used are the comparison of the $\mathrm{F}$ value and significance. If the value of $\mathrm{F}$ count $>\mathrm{F}$ table and significant $<0.05$, this research model is appropriate and the independent variables HR competence and intellectual capital have a simultaneous effect on the performance of MSMEs. This the hypothesis states:

\section{H1: HR competencies and intellectual capital have a positive effect on the performance of Sasirangan MSMEs (accepted)}

The partial effect of HR competence and intellectual capital on the performance of MSMEs is tested with a significance value. The criterion used to test the effect was significance $<0.05$. If the significance $<0.05$, there is a significant effect of the independent variables on the dependent variable. The significance value of the influence of HR competencies on the performance of MSMEs is 0.0311. The significance value of the influence of intellectual capital on the performance of MSMEs is 0,000 . So the competence of human resources and intellectual capital partially affects the performance of MSMEs. The independent variable which has a dominant effect on the dependent variable is done by comparing the $t$ value. If the $t$ value of the influence of the independent variables on the dependent variable is greater than the others, then the variable has a dominant effect. The $t$ value of the influence of $H R$ competence on the performance of MSMEs is 2.241 and the $t$ value of the influence of intellectual capital on the performance of MSMEs is 3.900. With the $t$ value of intellectual capital > the $t$ value of HR competence, it can be concluded that intellectual capital has a dominant influence on the performance of MSMEs. Thus the hypothesis states:

\section{H2 : Intellectual capital has a dominant effect on the performance of Sasirangan MSMEs (accepted).}




\subsubsection{Discussion}

\section{Description of HR Competencies, Intellectual Capital, and MSME Performance}

The results of the descriptive analysis show a description of HR competencies, intellectual capital, and the performance of the Sasirangan MSMEs. The average value of the description of HR competencies reaches 3 (three), including in the good category. The average value of the description of intellectual capital reaches 3 (three), including in the good category. The average value of the description of the performance of MSMEs reaches 3 (three), including in the good category.

\section{The Influence of HR Competencies and Intellectual Capital on MSME Performance}

Based on the results of data analysis, it is known that the findings of this study are the variables of HR competence and intellectual capital have a positive effect on the performance of the Sasirangan MSMEs in Sasirangan Village, Kec. Kertak Hanyar Banjar Regency and intellectual capital variables have a dominant effect on the performance of Sasirangan MSMEs in Banjar Regency. The following is a separate explanation of the two variables:

\section{a) The Influence of HR Competencies on the Performance of MSMEs}

The results of data analysis prove that HR competency has a positive effect on the performance of Sasirangan MSMEs (Prabhu, 2020). These results are in line with the research results (Ardiana \& Brahmayanti, 2010); (Mufidah, Eva, \& Fibriyani, 2017); (Sulistiyani, 2017); (Hidayat \& Agustina, 2020). This shows that the better the HR competency of a business actor, the more his ability will be increased (Adnan Rajak, Muhammad Thahrim, \& Maeda Pinoa, 2018) in managing a business or company, such as managerial skills, financial management, and marketing. The results of the study can be concluded that it is important to increase the competence of human resources and personal capacity for Sasirangan MSMEs actors to get attention and be carried out in a planned manner to produce MSMEs who have capabilities and personal characteristics. (Agustina, T.; Gerhana, 2020) which supports his ability to run a business and improve business performance. Self-development through increasing knowledge to encourage interest in learning (Agustina, 2019) the high level can be done through participation in training, workshops, workshops and so it is necessary because it will increase the quality and capacity of self / individual business actors. So it can be concluded that the competence of human resources or human capital is something that humans get through the learning process (Agustina, T.; Gerhana, 2020) so that they always hone their abilities and potential, wich are also very valuable assets and constitute non-physical capital (Endri, 2010) which is very important and has a big influence in the running of a business, by having good HR competencies (Hidayat \& Agustina, 2020), business actors / MSMEs especially Sasirangan MSMEs can improve their business performance.

\section{b) The influence of intellectual capital on the performance of MSMEs}

The results of data analysis prove that intellectual capital has a positive effect on the performance of Sasirangan MSMEs. Intellectual capital is one of the keys (Ramdani, Enas, \& Darna, 2019) to make progress in the business. A business actor/entrepreneur will find it difficult to develop if it is not supported by knowledge, experience, and expertise related to employee management, capital management, other resource management, and the ability to network with other entrepreneurs. This shows that the better the knowledge of a business actor, the more insight and most importantly will open wider opportunities for the marketing of products from these MSMEs. By strengthening intellectual capital, will increase self-competence (Ramdani et al., 2019), open the broadest insight possible, strengthen cooperation between entrepreneurs, increase bargaining power (bargaining position) of MSMEs players, and the positive impact will improve performance (Dwi, Astri, \& Susanto, 2008) MSMEs. MSMEs which are able to create a competitive advantage (Agustina, 2019) can increase the relationship between intellectual capital and company performance (probability). The results of this study have implications for the government to act as a facilitator and to provide guidance and motivate MSME actors to form an organizational forum. The organization's forum plays a role in educating the intellectual capital of MSME players so that they are able to compete and advance in class (Elfahmi \& Jatmika, 2019) in the global market. 


\section{Conclusions}

Based on the results of the research and discussion carried out, the following conclusions can be drawn:

1. The descriptive statistical results show the description of HR competencies, intellectual capital, and the performance of Sasirangan MSMEs including the good categories, where the average value of the description of HR competencies, intellectual capital, and the performance of MSMEs reaches 3 (three).

2. The results of data analysis show that the variables of HR competence and intellectual capital have a positive effect on the performance of Sasirangan MSMEs in Sasirangan Village, Kec. Kertak Hanyar Banjar Regency, which means that the better and the increased competence of human resources and intellectual capital in running a business, the better and the performance of the Sasirangan MSMEs will increase.

3. The intellectual capital variable has a dominant effect on the performance of Sasirangan MSMEs in Banjar Regency. With the better management of intellectual capital owned by MSMEs, the higher the performance obtained by these MSMEs.

\section{References}

Adnan Rajak, Muhammad Thahrim, \& Maeda Pinoa. (2018). Pengaruh Human Capital dan Kepuasan Kerja terhadap kinerja pegawai dinas lingkungan hidup kota ternate. Manajemen Sinergi (JMS), 5(2), 1-96.

Agustina, T.; Gerhana, W. . S. (2020). The Effect of Locus of Control, Learning, and Adversity Quotient Towards Micro Business Success (Study on Entrepreneurship under Foster Group of the Banjarmasin). Journal of Wetlands Environmental Management, 8(1), 21-32. https://doi.org/10.20527/jwem.v8i1.215

Agustina, T. (2019). Improving Business Performance Through Competitive Advantage: A Study On SMES In Banjarmasin, Indonesia. Eurasia: Economic \& Business, 6(26), 39-59.

Ardiana, I. D. K. R., \& Brahmayanti, I. A. (2010). Kompetensi SDM UKM dan Pengaruhnya Terhadap Kinerja UKM di Surabaya. Jurnal Manajemen Dan Kewirausahaan, 12(1), 42-55. https://doi.org/10.9744/jmk.12.1.pp.42-55

Dwi, M., Astri, P., \& Susanto, A. (2008). Analisis Pengaruh Human Capital Terhadap Kinerja Perusahaan (Studi Empiris pada Kantor Akuntan Publik di Indonesia). Jurnal Akuntansi Dan Keuangan, 10(1), 11-21. https://doi.org/10.9744/jak.10.1.PP.11-21

Elfahmi, S. H., \& Jatmika, D. (2019). PENGARUH INOVASI TERHADAP UKM NAIK KELAS MELALUI DAYA SAING PRODUK (Studi UKM Kuliner Rahajeng Catering Pati dan Indoburger Rembang). Media Mahardhika, 17(3), 481-487.

Endri. (2010). Peran Human Capital Dalam Meningkatkan Kinerja Perusahaan: Suatu Tinjauan Teoritis Dan Empiris. Jurnal Administrasi Bisnis, 6(2), 179-190.

Hidayat, A. T., \& Agustina, T. (2020). Pengaruh Pelatihan, Kompetensi, Kompensasi, dan Motivasi Kerja terhadap Kinerja Polisi Lalu Lintas Polresta Banjarmasin. BIEJ: Business Innovation \& Entrepreneurship Journal, 2(1), 48-53.

Mufidah, Eva, \& Fibriyani, V. (2017). PERAN WIRAUSAHA DAN KOMPETENSI SUMBER DAYA MANUSIA. Akademika, 15(2), 122-127.

Prabhu, J. J. (2020). A Study on Women Empowerment and Entrepreneurial Intention among Small Business of Women Entrepreneurs in the Czech Republic. Quantitative Economics and Management Studies, 1(5), 312318. https://doi.org/10.35877/454ri.qems176

Ramdani, F., Enas, \& Darna, N. (2019). PENGARUH MODAL INTELEKTUAL TERHADAP KINERJA PERUSAHAAN (Studi Kasus pada PT. Mayora Indah Tbk yang Terdaftar Di Bursa Efek Indonesia Periode 2007-2017). Business Management And Entrepreneurship Journal, 1(3), 91-102. 
Sanusi, A. (2014). Metodologi Penelitian Bisnis (4th ed.). Jakarta: Salemba Empat.

Sugiyono, S. (2011). Metode Penelitian Kuantitatif, Kualitatif dan R\&D. Bandung: Alfabeta.

Sulistiyani, S. (2017). Membangun Kompetensi Kapabilitas dalam Meningkatkan Keunggulan Bersaing. Serat Acitya, 6(1), 84-101. 